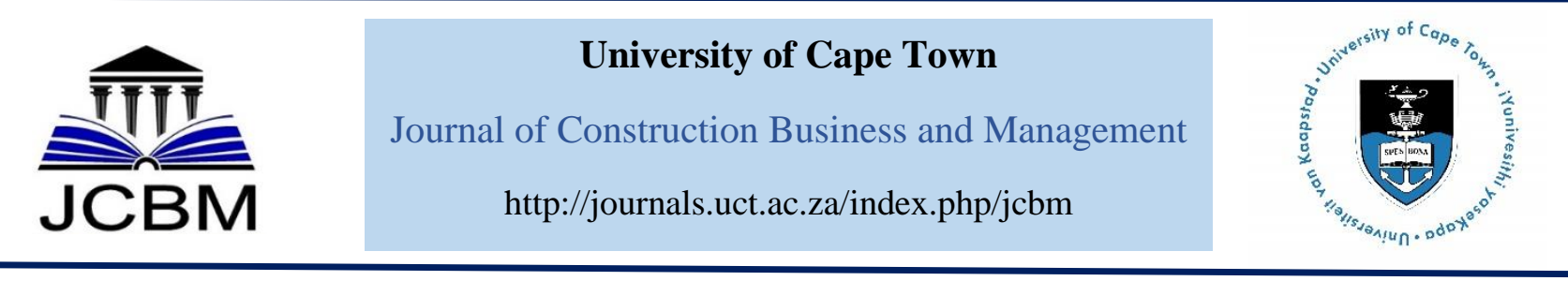

\title{
Consultants`Perspectives of Survival Strategies for Small and Medium Construction Firms at Infancy Stage
}

\author{
E. T. Adu ${ }^{1}$, A. D. Lamptey-Puddicombe ${ }^{2}$ and A. Opawole ${ }^{3}$ \\ ${ }^{1}$ Department Quantity Surveying, University of Uyo, Uyo, Akwa Ibom State, Nigeria \\ ${ }^{2}$ Department of Quantity Surveying, Rivers State University, Port-Harcourt, Rivers State, Nigeria \\ ${ }^{3}$ Department Quantity Surveying, Obafemi Awolowo University, Ile-Ife, Nigeria
}

Received 11 July 2019; received in revised form 3 October 2019 and 20 January 2020; accepted 25 January 2020. https://doi.org/10.15641/jcbm.4.1.792

\begin{abstract}
This study examines survival strategies for Small and Medium Construction Firms (SMCFs) at infancy stage as well as the factors affecting the adoption of these strategies. The study area is Uyo Metropolis in Akwa Ibom State, Nigeria. The study employed stratified random sampling technique to select a sample for the study. Primary data obtained from 103 validated questionnaires, administered to professionals in the built environment are analysed using percentage, mean score and Kruskal Wallis test. Results reveal that all the strategies examined in this study are significant for the survival of SMCFs at infancy stage; dominant among the factors are: innovativeness, required skills, willingness to take risk, entrepreneurial attitudes and behaviours, entrepreneurial organization structure and strategies, and financial resource management. The results further reveal that the dominant factors affecting the adoption of survival strategies for SMCFs at infancy stage are: availability and access to finance, the poor state of the country's infrastructure, poor managerial/executive capacity of the implementing agencies, characteristics of entrepreneurs and failure to adapt to the changing business environment. The study recommends that in addition to regular training to acquire required skills for effective management of the firms, SMCFs should also adopt any or a combination of the strategies highlighted, to survive in the current dynamic and competitive construction environment.
\end{abstract}

Keywords: Construction Firms, Construction Industry, Entrepreneurship, Stakeholders, Strategies.

\section{Introduction}

In a bid to address the issue of unemployment, government efforts have focused mainly on implementing one initiative or the other. This may not be unconnected to the notion that the solution to unemployment can only be achieved when people take to entrepreneurial activities (Okezie, Alex, \& Asoluka, 2013). This could also be attributed to the fact that small and medium-sized enterprises (SMEs) cover a wide range of industries and play an important role in both developed and developing economies (Sharma \& Bhagwat, 2006). Also, a booming and blooming SME`s sector is viewed as one of the significant characteristics of a flourishing and growing economy that every government intends to attain (Etim, Adabu, \& Ogar, 2017). Ongori and Migiro (2010) assert that in Africa, SMEs employ more than $40 \%$ of all new entrants to the labour force because they are labour intensive.

Similarly, Sharma and Bhagwat (2006) assert that the SMEs sector accounts for 40 per cent of industrial production, 35 per cent of total 20 exports and provides about 80 per cent of employment in industrial production in India. The economic development of most nations such as Malaysia, Singapore, Hong Kong, South Korea and Taiwan is intrinsically linked to the development of the SME sector. Study shows that by the end of $2012,80 \%$ of China's employment and $60 \%$ of the country's GDP had been provided by the 13 million SMEs that constitute more than $99 \%$ of all the country's enterprises (Gao \& Banerji, 2015). In Nigeria, the contribution of SMEs to the economy is of notable significance as $70 \%$ of the country's employment is generated by SMEs (Aina, 2007).

\footnotetext{
${ }^{1}$ Corresponding Author.

Email address: teatea4t@yahoo.com
} 
Entrepreneurship has permeated every industry and arguably every career of choice (Allen, 2003), the way people think, reason and act are opportunity-based, holistic in approach and leadership balanced (Timmons \& Spinelli, 2004). As part of initiatives to address the issue of unemployment, the communiqué of the World Conference on Higher Education held in Spain implored tertiary institutions to produce entrepreneurship graduates towards a sustainable economy (Udoudoh, 2018). Many countries have also included entrepreneurship training at secondary schools and higher education institutions since the 1990s (Duell, 2011). As part of the effort, the Nigeria government in 2006 gave a directive through the Higher Education Institutions (HEIs) to immediately include Entrepreneurship Education (EEd) as a compulsory course for all students with effect from the 2007/2008 academic session (Etuk, Offiong, \& Usip, 2018). Despite the numerous laudable programmes, policies, schemes and financial investment by the government of different nations, many SMEs fail to grow beyond the infancy stage. The situation in Nigeria is not much different as entrepreneurial development is still very slow, and many SMEs find it difficult to survive the turbulence in the market economy (Diyoke, 2014). The situation in the construction industry is worrisome. This is because the industry is more susceptible to high failure compared to SMEs in other sectors, such as manufacturing and agriculture. Odeyinka, Kaka and Mortledge (2003) had earlier reported a high rate of failure in the construction industry compared to other sectors of the economy. The impact of the failure is endemic and disruptive to the construction industry, individuals and the society at large (Scarborough, Zimmere, \& Wilson, 2008; Abd-Hamid et al., 2015). The construction business is limited to $80 \%$ in many construction companies in what is believed as a lack of business opportunities and the recent world economic decline (Adesiyan, 2016).

Several programmes and initiatives in resuscitating SMEs, particularly in developing countries, have no clear directive of survival strategy for entrepreneurship at the infancy stage. The infancy stage of entrepreneurship is a phase before the maturity stage in the business lifecycle, which is about a maximum of six to seven years from the commencement of the business. Most entrepreneurs at this stage are immature and inconsistent with the needs of a business-driven system. Ndabeni (2008) states that many new ventures fail and only a few attain survival and sustainability rating in both developed and developing countries. Turyakira (2018) reports a continuous business failure of small and medium-sized enterprises in developing countries. Research findings in Nigeria reveal that most SMEs collapse within their first five years of existence (Aremu \& Adeyemi, 2011). The authors add that a smaller percentage goes into extinction between the sixth and tenth years, while only about five to ten per cent of young companies survive and grow to maturity. In corroboration, Ajayi, Peace and Mafimidiwo (2015) confirm a high mortality rate of business organisations in Nigeria (including the construction industry) due to poor performance. The situation is not much different in other countries (Thwala \& Phaladi, 2009; Adcorp, 2012). This may not be unconnected to the fact that today's business environment characterised by more volatility and uncertainty than ever before, with globalization being the order of the day has become a reality for all players on the domestic and international scene (Naicker \& Saungweme, 2009). Collett, Pandit and Saarikko (2014) identify poor management, high debt in the adverse macroeconomic and microeconomic environment as three critical factors responsible for the failure of SMEs. In a similar study, Santini, Favarin, Nogueira, Oliveira and Ruppentthal (2015) identify eleven major factors causing mortality of small businesses and classified them into two. The first group is the internal and external factors, and the second group of factors are related to the owner-manager, to the business itself and the environment.

Previous studies have attempted to address this problem and also to suggest possible solutions in some developing countries (Adejumo \& Olaoye, 2012; Okezie et al., 2013; Diyoke, 2014; Bouazza, Ardjouman \& Abada, 2015; Abd-Hamid et al., 2015; Igwe, Newbery, White \& Nihar, 2017; Jegede, 2018), yet there is a dearth of research on strategies for survival of SMEs at infancy stage particularly in the construction sector. This may be because researchers have not recognized the vacuum created by the dead and ailing firms rendering investigation of strategies for its survival crucial. In order to investigate the subject and contribute to narrowing the knowledge gap, this study provides insight to the survival strategies at the infancy stage of construction entrepreneur with the view to ensuring sustainable entrepreneurship in the built environment. The objectives of the study are to examine the survival strategies at infancy stage for SMCFs and to assess further the extent of the factors that affect the adoption of these strategies from consultants' perspectives in Uyo Metropolis of Nigeria. The result of this study should provide useful information for construction entrepreneurs on survival strategies to be adopted, especially at the infancy stage and also ensure smooth take-off for potential entrepreneurs. The proposed strategies will not only ensure the survival of SMCFs but will also promote the globalization of SMEs, improve economic status and reduction in poverty level.

\section{Entrepreneurship and SMCFs}

Entrepreneurship has become a global topic, and yet it has no universally accepted definition (Dana, 2001). Baron and Henry (2011) attempt to describe entrepreneurship as a field that seeks to understand how opportunities to create something new (such as products or services) arise, and are created by individuals who then use various means (for instance launching a new business) to exploit or develop them. Oladun (2012) views entrepreneurship as creating a product, a service, task or activity that meets the needs of the society with its attendant financial rewards and risks. Similarly, Nwoke, Adebayo and Olutope (2017) define entrepreneurship as the process which involves the effort of an individual or individuals in identifying viable business opportunities in an environment and managing the resources needed to exploit them. Entrepreneurship is, therefore, a medium that intends to meet the needs of ordinary citizens and the nation by creating a product or service of values. Most governments, especially in the developing countries in an attempt to strengthen their socio-economic development, 
have redirected their focus on entrepreneurship and formation of new firms and industries (Rattanawiboonsom \& Ali, 2016). According to Bondinuba (2012), small firms are classified as having between 10 and 99 employees, while medium firms have between 100 and 200 employees. This classification defines SMCFs, which is an extension of SMEs in the construction sector.

The construction industry plays a complementary role in entrepreneurship in both developed and developing countries. Studies reveal that the construction industry is a key provider of employment opportunities worldwide perhaps second to agriculture. It is the primary provider in urban areas, especially in the building sector involving both new and maintenance work which is labour intensive (Women in Informal Employment: Globalising and Organising (WIEGO, 2018). The industry is identified as one of the leading economic indicators in terms of building permits that offers foresight into future real estate supply levels of which a high volume indicates a vibrant construction industry with an attendant increase in GDP (Smith, 2018). The construction industry aids the development of entrepreneurship by creating an enabling environment through the provision of physical infrastructures, such as transportation, access to power, water and raw materials. Without these facilities, entrepreneurship activities will suffer serious consequences such as an increase in production cost and associated risks which impact economic growth and development. Efforts toward these provisions enhance the relevance of the industry in wealth creation and job opportunities which make the industry one of the best sectors positively complementing government efforts in meeting the needs of the citizenry. In order to sustain these laudable achievements, construction entrepreneurs need to capture economic value through the exploration and exploitation of construction businesses (Abd-Hamid et al., 2015), both at local and national levels. This is made possible because of the multi-disciplinary approach of the industry which involves different trades, professionals, skilled and unskilled personnel producing value chain through interdependency in providing necessary inputs at different phases of the project from inception to completion (Akinsiku \& Olubunmi, 2014). This is a good platform for entrepreneurs to thrive, especially among young built environment graduates (Adu \& Oladele, 2018). These include contracting and subcontracting works such as aluminium works, professional glaziers, finishing works, material manufacturing as well as labour and skills management on site. All these can be accommodated in the built environment (Dada, 2017) apart from the core management services required at different project lifecycle.

\section{Survival and Survival Strategy for SMCFs}

Survival is one of the primary ways of measuring business success apart from other factors such as profits, return on investment, sales growth, and the number of personnel employed, happiness and corporate reputation (Schmidpeter \& Weidinger, 2014). A considerable number of studies in the entrepreneurship field view the concept of survival as similar to success (Praag, 2003;
Reijonen \& Komppula, 2007). Reijonen and Komppula (2007) find a similarity between survival and success and define survival as continued business operations, and failure as going out of business. Praag (2003) posits that the longer a business can survive in the market place and prevent involuntary exit, the more successful it is. Survival is therefore fundamental to the success of entrepreneurship provided a right strategy is employed. Strategies are well-planned series of actions, ways and means of making use of available human and non-human resources intelligently and skilfully to achieve a goal. According to Yusuf and Dansu (2013), the concept of strategies is built on the future ability of a business to operate ethically and contribute to economic development while improving the quality of life for its workforce, the local and global community and future generations. Strategies are an integral part of every endeavour and are fundamental to the formation, survival and successful growth of entrepreneurship in today`s competitive business environment. The formulation and implementation of these strategies might hold the key to the growth and survival of SMEs. An understanding of sources, causes and nature of the failure of SMEs is a significant determinant of the choice of strategy to adopt for organisation survival. Investigation of causes of factors responsible for premature death or failure of SMEs has received much research attention. Failure of SMEs is attributed to several factors which include unethical practices, lack of information, economic recession, soliciting or offering kickbacks, incompetence, poor infrastructure, lack of quality education, ineffective credit and financial system, corruption and political instability (Tarus \& Nganga, 2013; Ononogbo, Joel, \& Edeja, 2016; African Economic Outlook, 2017; Igwe, Newbery, White, \& Nihar, 2017). Similarly, Agwu and Emeti (2014) identified other factors contributing to this premature death of SMEs such as insufficient capital, irregular power supply, infrastructural inadequacies, lack of focus, inadequate market research, lack of succession plan, inexperience and lack of proper bookkeeping, inability to separate business and personal finances.

Etim et al. (2017) in a study on the influence of entrepreneurial orientation as a survival strategy for SMEs in Nigeria, affirm that there is a significant positive relationship between the survival of SME's and entrepreneurial orientation variables which include innovation, risk-taking and pro-activeness. Fadanhusi (2012), in a similar study on the growth of small businesses, reveals a positive correlation between survival strategies via innovativeness and the survival of SMEs. Okpara (2009), also, observes that SMEs that are driven by innovation have a higher survival rate than those with a conservative attitude. Abd-Hamid et al. (2015) in a study on predictors for the success and survival of entrepreneurs in the construction industry find that the success and survival of construction enterprises depend on success factors which have a direct impact on the business success, not only in the short-term but also, the long-term. Ali (2018), in a recent case study on one of the most successful entrepreneurs in the water industry in Basra city, shows that five strategies are used by the founder to keep his firm alive. These include a sale on credit (buy now and pay later), groundwater to produce freshwater for 
low cost, care for wholesale and retail dealers and quality products, technology investment for cost reduction, and social network and family support. Factors such as entrepreneurial attitudes and behaviours have been identified as necessary for firms of all sizes to prosper and grow (Kraus, 2013). Man et al. (2002) also identify entrepreneurial competency as important in a firm's performance and competitiveness. Competitiveness, conversely, has a variety of attributes such as personality traits, skills and knowledge that enhance survival of entrepreneurs. Traditional factors such as age and size of the firm, organizational strategies; individual and environmental factors are also found to have an impact on the survival of SMEs (Geroski, Mata, \& Portugal, 2010). Other factors such as ambition, independence, selfconfidence, risk-taking, vision, creativity, energy, passion, and commitment are vital traits expected of successful entrepreneurs (Hisrich, Shepherd, \& Peters, 2005; Ogbo \& Agu, 2012). In addition to the above review, which provides insight into the survival strategies for entrepreneurship, comprehensive literature identifies 18 variable factors as presented in Table 1 . The concern of this study, however, is to examine the variables that constitute survival strategies for SMCFs at the infancy stage.

Table 1: Survival Strategies for Construction Entrepreneurship

\begin{tabular}{lll}
\hline S/n. & Factors & Sources \\
\hline 1 & Entrepreneurial organization structure and strategies & Chen and Lee, 2007 \\
2 & Competitive aggressiveness & Venkatraman, 1989 \\
3 & Entrepreneurial attitudes and behaviours & Kraus, 2013; Morris et al., 1996 \\
4 & Required skills & Osemeke, 2012; Ogbo and Agu, 2012 \\
5 & Autonomy & Lumpkin and Dess, 1996 \\
6 & Organizational flexibility and speed & Morris et al., 2012 \\
7 & Financial resources and management & Wiklund et al., 2009 \\
8 & Adaptability & Morris and Kuratko, 2003 \\
9 & Entrepreneurial competencies & Ma et al., 2002 \\
10 & Corporate venturing & Antoncic and Hisrich, 2001 \\
11 & Willingness to take risk & Rauch et al., 2009 \\
12 & Environmental factors & Geroski et al., 2010 \\
13 & Proactiveness & Rauch et al., 2009 \\
14 & Innovativeness & Rauch et al., 2009 \\
15 & Human resource management & Anyadike et al., 2012 \\
16 & Social network & Mboko and Smith-Hunter, 2009 \\
17 & Family support & Mboko and Smith-Hunter, 2009 \\
18 & situational responsiveness & Mboko and Smith-Hunter, 2009 \\
\hline
\end{tabular}

\section{Factors Affecting the Adoption of Survival Strategies for SMCFs}

Identifying survival strategies for sustainable entrepreneurship is not sufficient in helping entrepreneurs to achieve the desired result. Entrepreneurs need to understand the nature and dynamics of challenges and difficulties inherent to the implementation of these strategies. This is because entrepreneurs operate in a competitive environment coupled with constraining internal organizational factors which determine the success or failure of any adopted strategy or initiative. However, these factors are inherent in every business, small or large; understanding and the priority accorded to these factors are important to the adoption of the survival strategies for entrepreneurs. Adopting a strategy for the survival of entrepreneurship is therefore critical to its continued existence and success even beyond the infancy stage. Previous studies reveal that failure of several programmes and many support initiatives to revamp entrepreneurship by past and current governments of Nigeria was blamed on poor implementation (Okezie et al., 2013; Adejumo and Olaoye, 2012).

Similarly, Etim et al. (2017) also blamed this on the initial response of the policymakers in Nigeria as either not proactive or reactive enough to respond to the alarming rate of the depth of problems faced by SME`s or understand the magnitude of the difficult conditions faced by owners of SME`s. Igwe et al. (2017) identify five major institutional barriers which also affect the adoption of survival strategies in Nigeria as follows: an ineffective credit and financial system, corruption, political instability and an inefficient legal system, poor infrastructure, lack of quality education, and religion, traditions and customs. Entrepreneurship operates within environmental factors such as economic, political, financial, technological and legal positions of an organization (Taormina \& Lao, 2006). Inability to assess effective management poses a threat to its success and survival. Besides, Igwe, Amaugo, Ogundana, Egere and Anigbo (2018) identify insecurity, bribery, bureaucratic delays, power outage and lack of market access among the existing challenges of entrepreneurship.

Infrastructure deficit in most developing countries has retarded efforts of entrepreneurs in the adoption of rewarding initiatives for its survival in the market place. Onodugo and Onodugo (2015) raise a serious concern on the state of Nigeria's infrastructure and view it as a nightmare to both entrepreneurs and the rest of the country's population. The authors add that with the existing infrastructure or non-existence in some places; the cost of doing business has risen tremendously. The relocation of some multinational organizations from Nigeria to Ghana a few years ago was not unconnected with the poor state of infrastructure. Several other factors that could hinder entrepreneurs in adopting recommended 
strategies have been identified in the literature. These include lack of access to external financing, low human resources, characteristics of entrepreneurs, managerial capacities, location of the enterprise, access to information, inadequate business planning, technological capacities, access to finance, human resources capacities, corruption, lack of motivation, and education background of the entrepreneur (Haynes, 2003; Ciavarella et al., 2004;
Dionco-Adetayo, 2004; Ucbasaran, Westhead, \& Wright, 2004; Morse, Fowler \& Lawrence, 2007; Krasniqi, 2007; Pasanan, 2007; Sridhar \& Wan, 2010; Sidika, 2012; Onodugo \& Onodugo, 2015; Bouazza Ardjouman \& Abada, 2015). The summary of literary works on 31 variable factors affecting the adoption of survival strategies for SMCFs is as presented in Table 2.

Table 2: Factors affecting adoption of survival strategies for entrepreneurship

\begin{tabular}{|c|c|c|}
\hline $\mathbf{S} / \mathbf{n}$. & Factors & Sources \\
\hline 1 & Lack of management skills and training & Bouazza et al., 2015 \\
\hline 2 & Characteristics of entrepreneurs & Ciavarella et al., 2004 \\
\hline 3 & Managerial capacities & Olawale and Garwe, 2010 \\
\hline 4 & Lack of resources for implementation & Ofori, 1994 \\
\hline 5 & Contractor's incompetence/inadequacies & Ogunlana et al., 1996 \\
\hline 6 & Human resource capacities & Lee, 2001 \\
\hline 7 & Lack of commitment to solve its problems & Ofori, 1994 \\
\hline 8 & Technological capacities & Drucker, 1985; Morse et al., 2007 \\
\hline 9 & The poor state of the country's infrastructure & Ogunlana et al., 1996; Onodugo and Onodugo, 2015 \\
\hline 10 & Access to finance & Krasniqi, 2007 \\
\hline 11 & The poor executive capacity of the implementing agencies & Ofori, 1994 \\
\hline 12 & Low technological capacities & Morse et al., 2007; Bouazza et al., 2015 \\
\hline 13 & Corruption & Onodugo and Onodugo, 2015 \\
\hline 14 & In-appropriateness of some of the recommendations & Ofori, 1994 \\
\hline 15 & Inconsistent government policies & Onodugo and Onodugo, 2015 \\
\hline 16 & Problems caused by clients and consultants & Ogunlana et al., 1996 \\
\hline 17 & Failure to adapt to the changing business environment & Onodugo and Onodugo, 2015 \\
\hline 18 & Lack of motivation factors & Dionco-Adetayo, 2004 \\
\hline 19 & Lack of support from expected quarters & Rahman and Singh, 2014 \\
\hline 20 & Location of the enterprise & Sridhar and Wan, 2010; Leidholm, 2002 \\
\hline 21 & Education background & Almus, 2002; Martinez et al., 2007 \\
\hline 22 & Access to information & Okumus, 2000 \\
\hline 23 & Inadequate business planning & Ahmad and Seet, 2009 \\
\hline 24 & Networking & Ciavarella et al., 2004 \\
\hline 25 & Problems caused stakeholders & Ogunlana et al., 1996 \\
\hline 26 & Cumbersome legal and regulatory constraints & Bouazza et al., 2015 \\
\hline 27 & Resource allocation & Okumus, 2000 \\
\hline 28 & Operational plans & Okumus, 2000 \\
\hline 29 & Control mechanism & Thorpe and Morgan, 2007 \\
\hline 30 & Cooperative management & Thorpe and Morgan, 2007 \\
\hline 31 & Organisational behaviour or culture & Okumus, 2000 \\
\hline
\end{tabular}

\section{Methodology}

The study utilises primary data obtained through a field survey in order to achieve the objectives. The study area is Uyo, the capital of Akwa Ibom State, the leading oilproducing state in the Niger Delta. Uyo is also one of the fastest-growing state capitals in terms of infrastructure and development within the South-South region of Nigeria (Olubajo \& Kuma, 2017). The choice of the area was to explore the possibility of reducing the mortality rate among SMCFs and reviving ailing ones majorly at the infancy stage. This is with the view to ensuring their contributions to the "industrialization" agenda of the government as well as sustaining the contributions of these firms to both the local and national economy. The purpose of the industrialization agenda is to rebrand Akwa Ibom State from "civil service" state to industrialize base of Nigeria. The study population consists of professionals in the construction industry.
Since professionals in the SMCFs within Uyo metropolis are used in this study, the stratified random sampling technique is employed to determine the sample of the study. The technique is important as it further enhances the sampling precision of the study population (Kumar, 2005). The stratification was done according to the respective professional bodies. The professionals include Architects, Builders, Engineers, Estate Surveyors and Quantity Surveyors. Before the distribution of the questionnaire, a pre-test to evaluate the proper understanding of the questions and to ascertain whether the questionnaire items adequately cover the constructs and objectives of the study was undertaken. The questionnaire was moderated by five research experts in the field of entrepreneurship and the built environment. The pilot study is considered necessary to ascertain the reliability of the questionnaire when used in the population of the study. This process assists in eliminating any potential problems of the research instrument and in 
testing the validity and workability of the instrument. Inputs are collated, which result in 15 variable strategic factors for the survival of entrepreneurship and 23 variable factors affecting the adoption of the strategy were adopted in the production of the final questionnaire used in this study. The reliability was also tested and found to be high with Cronbach $\alpha$ of 0.67 and 0.82 of variable factors for survival strategies and factors affecting the adoption of the strategies, respectively. Thus, it is deemed acceptable, since the value of alpha is desirable with the range higher than 0.6 (Hair, Anderson, Tatham \& Black, 2006). The reliability as a quality criterion helps to minimize errors and give stable results of data collection.

The sample frame of 272 was obtained from the directories of registered professionals from their respective chapters in the state. This comprises of the Nigerian Institute of Architects (NIA), Nigerian Institute of Builders (NIB), Nigerian Institute of Engineers (NSE), Nigerian Institute of Estate Surveyors and Valuers (NIESV) and the Nigerian Institute of Quantity Surveyors (NIQS). The sample size of the study is determined using Taro Yamane formula for finite populations (Olusanya, 2018), which states that

$$
n=\frac{N}{1+N\left(e^{2}\right)}
$$

Where $n$ is the sample size, $N$ is the finite population, $e$ is the level of significance (0.05), and 1 is unity.

The breakdown of the sample frame and sample size for each category is shown in Table 3 . Thus, a sample size of 235 is adopted for the study. The minimum qualification of the respondents is Higher National Diploma (HND) which is also minimum qualification for corporate membership of professional bodies in the Nigerian built environment; 83 per cent have over five years of professional work experience in the industry.

Table 3: Sample Frame and Sample Size of the Study

\begin{tabular}{lcc}
\hline Professional & Sample frame & Sample size \\
\hline Architects & 63 & 54 \\
Builders & 22 & 21 \\
Engineers & 93 & 76 \\
Estate Surveyors & 55 & 48 \\
Quantity Surveyors & 39 & 36 \\
Total & 272 & 235 \\
\hline
\end{tabular}

Section (A) of the questionnaire solicits data on the demographic characteristics of respondents. The aim is to establish a relationship between responses and organisational characteristics of the respondents. Section (B) uses a 5-point Likert scale ranging from 1 (no importance) to 5 (very high importance) to establish the level of importance of survival strategies for SMCFs based on the perception of respondents. The study subsequently seeks the perception of respondents on the severity of factors affecting the adoption of the survival strategies for SMCFs using a five-point Likert scale ranging from 1 (no effect) to 5 (very high effect). The questionnaires were self-administered, and one hundred and nine questionnaires were returned in which six feedbacks were identified as invalid due to incomplete information. One hundred and three valid questionnaires were used for the analysis giving a valid response rate of $44 \%$. The percentage is higher than the $20-30 \%$ returned rate for research conducted within the construction industry. Therefore, the result of the survey cannot be considered as biased or of little significance (Moses \& Stahelski, 1999; Akintoye \& Fitzerald, 2002). The collected data were checked for completeness and consistency before data processing and analysis. The views of respondents were compared to determine whether or not they differ in their perception of factors constituting survival strategies and factors affecting the adoption of the strategies. This leads to the postulation of two hypotheses:

$H_{o l}$ : There is no significant variation in the survival strategies for SMCFs among the perceptions of the various professionals; and

$H_{o 2}$ : There is no significant variation in the effect of the factors affecting the adoption of the strategy for SMCFs among the perceptions of the various professionals.

The two hypotheses of the study are analysed using Kruskal Wallis tests. Mean Score (MS) is used to determine the level of significance of each factor by five expressions defined by the intervals 0.8 with 3.4 as a cutoff for high significance based on Kazaz, Manisali and Ulubeyli (2008). The ranking of the factors is determined based on the mean item score of each item calculated by the following equation:

$M S=\frac{\sum\left(R P_{i} \times R_{i}\right)}{n}$

Where: $M S=$ Mean Score, $R P i=$ Rating point $i$ (range from 1-5), $R i=$ response to rating point, $i$ ) and $n=$ total responses $=$ summation of $R$ i from $1-5$

\section{Results and Discussion of Findings}

Results arising from the analyses of the data collected for the study are presented below. This includes the test of the two hypotheses; evaluation of the survival strategies for SMCFs; and the relative effect of the factors affecting adoption of the strategies for SMCFs.

\subsection{Tests for the two hypotheses of the study}

The study tests whether or not there is significant variation in the perception of various professionals of the survival strategies for SMCFs and the effect of the factors affecting the adoption of the strategies. This became necessary to ascertain the level of importance of the survival strategies for SMCFs and variance of the factors militating against the adoption of the strategies among the SMCFs or whether it could be generalized. This is achieved using a Kruskal-Wallis test. Kruskal-Wallis Test $(\mathrm{H})$ is a nonparametric statistic which is an alternative to the one-way analysis of variance test (Pallant, 2007; Udofia, 2011). This test is used when the assumptions for the parametric statistic cannot be satisfied or are violated (Pallant, 2007). One of the assumptions of the parametric techniques is that the level(s) of measurement of the variable(s) should be an interval or ratio scale otherwise the non-parametric alternative is to be considered (Pallant, 2007). These criteria are satisfied by the data used for this study, hence 
the choice of the Kruskal-Wallis (H) Test. The rule for rejection or non-rejection of the hypothesis is that if $\mathrm{p}$ value $>0.05$, the hypothesis is accepted, but if $p$-value $\leq$
0.05 , the hypothesis is rejected. The results are presented in Table 4 and Table 5.

Table 4: Kruskal-Wallis H-Test for variation in of the importance of survival strategies for construction entrepreneurship in Uyo Metropolis of Nigeria

\begin{tabular}{lllllll}
\hline Parameters Tested & Respondent groups & $\mathbf{N}$ & $\mathbf{x}^{\mathbf{2}} \mathbf{c a l}$ & $\mathbf{x}^{\mathbf{2}} \mathbf{t a b}$ & P-Value & Decision \\
\hline The relative importance of survival & Architects & 15 & 1.5 & 9.488 & 0.827 & Accept \\
strategies & Builders & 15 & 1.233 & 9.488 & 0.873 & Accept \\
& Engineers & 15 & 2.067 & 9.488 & 0.723 & Accept \\
& Estate Surveyors & 15 & 4.5 & 9.488 & 0.343 & Accept \\
& Quantity Surveyors & 15 & 2.867 & 9.488 & 0.58 & Accept \\
\hline
\end{tabular}

*N= Number of factors

Table 5: Text of Variation of Effect of the Factors Affecting the Adoption of the Survival Strategies among the Respondents

\begin{tabular}{|c|c|c|c|c|c|c|}
\hline Parameters Tested & Respondent groups & $\mathbf{N}$ & $\mathrm{x}^{2}$ cal & $\mathbf{x}^{2} \mathbf{t a b}$ & P-Value & Decision \\
\hline \multirow{5}{*}{$\begin{array}{l}\text { The relative importance of survival } \\
\text { strategies }\end{array}$} & Architects & 23 & 0.241 & 9.488 & 0.994 & Accept \\
\hline & Builders & 23 & 0.677 & 9.488 & 0.954 & Accept \\
\hline & Engineers & 23 & 1.068 & 9.488 & 0.899 & Accept \\
\hline & Estate Surveyors & 23 & 0.293 & 9.488 & 0.99 & Accept \\
\hline & Quantity Surveyors & 23 & 1.193 & 9.488 & 0.879 & Accept \\
\hline
\end{tabular}

\section{$* \bar{N}=$ Number of factors}

The results of the Kruskal Wallis test presented in Table 4 indicate that the calculated chi-square $(x 2)$ values obtained for all the respondent groups, that is, 1.500, $1.233,2.068,4.500$ and 867 are less than the table value of 9.488. The indicative hypothesis is therefore accepted, and the inference is that the perceptions of construction professionals on the relative importance of the survival strategies for SMCFs do not differ significantly. Also the p-value (asymptotic significance) for each of the respondent group, that is, $0.827,0.873,0.723,0.343$ and 0.580 is greater than 0.05 further confirm that there is no variation in the perceptions of the respondent groups regarding the importance of the survival strategies for SMCFs in the study area. This may be attributed to the general understanding of the respondents of the relationships between strategies and business survival. The result supports Nobre and Silva (2014) and Fadanhusi (2012) that there is a positive correlation between adoption of survival strategies and SME`s survival.

Similarly, the results in Table 5 indicate that the calculated chi-square $(x 2)$ value obtained for all the respondent groups, that is, $0.241,0.677,1.068,0.293$ and 1.193 are less than the table value of 9.488 implies that there is no significant variation in the perceptions of construction professionals on the effect of the factors affecting the adoption of the survival strategies for SMCFs in the study area. The p-value (asymptotic significance) of $0.994,0.954,0.899,0.990$ and 0.879 all greater than 0.05 which also confirm that the effect of the factors affecting the adoption of the survival strategies for SMCFs does not vary significantly among the selected construction professionals involved in the study. This supports the study by Gilmore, Carson, and Rocks (2006) who blamed the problems of adoption on several particular characteristics and constraints of SMEs such as lack of time, limited budgets, lack of marketing expertise, lack of market information, and lack of planning. Consequently, the two research hypotheses that the perceptions of construction professionals of the relative importance of the survival strategies for SMCFs, as well as the relative effect of the factors affecting the adoption of the strategies do not differ significantly in the study area were retained. Besides, the overall view of the respondents is further analysed in the following sections.

\subsection{Evaluation of Survival Strategies of SMCFS}

This section consists of an evaluation of fifteen variables of survival strategies for construction entrepreneurship (which also include SMCFs) identified through literature review and pilot survey. The combined data of the respondents were analysed to determine the perception of selected project team members on the level of importance of survival strategies SMCFs. The decision to combine the data for the analysis is based on the conclusion earlier drawn that there is no variation in the perceptions of the respondents in the level of importance of survival strategies for SMCFs growth in the study area. The result of the analysis, which indicates the MS of each factor, standard deviation (SD), rank and remark column indicating the significance of each factor are as presented in Table 6.

The result of the analysis shows that all the factors are significant with the MS of the factors range as $3.43 \leq \mathrm{MS} \leq$ 4.80. Ten of the factors have very high significance (VHS) with the remaining five factors ranking high significance (HS). The results reveal that the innovation is the most significant survival strategy, while the least factor is autonomy. Among the top five most significant survival strategies for construction entrepreneurial are innovativeness $(\mathrm{MS}=4.80, \mathrm{SD}=0.81)$, required skills $(\mathrm{MS}=4.70, \mathrm{SD}=0.70)$, willingness to take risk $(\mathrm{MS}=$ 4.67, $\mathrm{SD}=0.83$ ), entrepreneurship attitudes and behaviours ( $\mathrm{MS}=4.60, \mathrm{SD}=1.07)$, and entrepreneurial organization structure and strategies $(\mathrm{MS}=4.55, \mathrm{SD}=$ 0.79). However, the five least significant factors are environmental factors ( $\mathrm{MS}=4.18, \mathrm{SD}=1.28$ ), human 
resource management $(\mathrm{MS}=3.99, \mathrm{SD}=1.62)$, corporate venturing $(\mathrm{MS}=3.83, \mathrm{SD}=1.24)$, competitive aggressiveness $(\mathrm{MS}=3.50, \mathrm{SD}=1.10)$, and autonomy $(\mathrm{MS}=3.43, \mathrm{SD}=1.08)$.

Table 6: Survival Strategies for Construction Entrepreneurship at Infancy Stage

\begin{tabular}{llcccc}
\hline S/n. & Factors & Mean score & Std. Deviation & Rank & Remarks \\
\hline 1 & Innovativeness & 4.80 & .81 & $1^{\text {st }}$ & VHS \\
2 & Required skills & 4.70 & .70 & $2^{\text {nd }}$ & VHS \\
3 & Willingness to take risk & 4.67 & .83 & $3^{\text {rd }}$ & VHS \\
4 & Entrepreneurial attitudes and behaviours & 4.60 & 1.07 & $4^{\text {th }}$ & VHS \\
5 & Entrepreneurial organization structure and strategies & 4.55 & .79 & $5^{\text {th }}$ & VHS \\
6 & Financial resource management & 4.44 & .88 & $6^{\text {th }}$ & VHS \\
7 & Proactiveness & 4.41 & .55 & $7^{\text {th }}$ & VHS \\
8 & Organizational flexibility and speed & 4.38 & 1.08 & $8^{\text {th }}$ & VHS \\
9 & Adaptability & 4.34 & .57 & $9^{\text {th }}$ & VHS \\
10 & Entrepreneurial competencies & 4.30 & 1.04 & $10^{\text {th }}$ & VHS \\
11 & Environmental factors & 4.18 & 1.28 & $11^{\text {th }}$ & HS \\
12 & Human resource management & 3.99 & 1.62 & $12^{\text {th }}$ & HS \\
13 & Corporate venturing & 3.83 & 1.24 & $13^{\text {th }}$ & HS \\
14 & Competitive aggressiveness & 3.50 & 1.10 & $14^{\text {th }}$ & HS \\
15 & Autonomy & 3.43 & 1.08 & $15^{\text {th }}$ & HS \\
\hline
\end{tabular}

The result of this study supports the previous findings of Ifemkwe and Adedamola (2016), who found a statistically significant relationship between survival strategies and SMEs' sustainability. A similar study conducted by Jegede (2018) further confirms the result of this finding stating that the innovative ability is a sine-qua-non for the survival of the entrepreneur and growth of the small business to a large business. Findings reveal innovation strategy as the most significant for the survival for SMCFs at the infancy stage. Innovation involves the analysis of dynamic competition, the pattern of investment, pricing and brand recognition strategies (Schmalensee, 2002). Supporting the findings from the previous study, Hurley and Hult (2008) classified innovation into two dimensions which include innovativeness and innovation capability. According to the authors, innovative firms accept and adopt new ideas, products, processes and organizational forms while innovation capability equips firms with an ability to implement and realize innovation. In construction, innovative ideas are critically needed not only to survive the turbulent stage of survival but also to meet the needs of clients in given value for their hard earn income.

Required skill in any endeavour is an essential attribute that differentiates high performers from average performers. In order for an entrepreneur to weather the storm of challenges at the infancy stage, it is highly necessary to acquire the required skills. This is in agreement with Barbero, Casillas and Feldman (2011) who assert that SMEs should possess high capabilities in specific functional areas, to grow fast and intensively. According to Olagunju (2004), entrepreneurial skill is the individual ability to create a new business through the exploitation of an idea in other to benefit both the individual and society. Skills are required in daily operation, finance, marketing, human and non-human resources, as well as general management. Construction entrepreneurship, among other things, needs creative, innovative, managerial, analytical, marketing, communicative, technical, and interpersonal skills in order to survive the present competitive and volatile economic and political environment. These also help to achieve maximum profitability and productivity sufficient for the survival of the organisation at the infancy stage. The finding is also in agreement with the study of Akhamiokhor (2017), which reveals a significant relationship between employee productivity and human resource strategies in the selected SMEs. Another critical strategy identified in the study for the survival of SMCFs is the willingness to take risks. A successful construction entrepreneur is viewed as a risk-taker who anticipates risks and the potential impact in advance. Generally, the construction project is a complex endeavour inherent with risks and uncertainties. Construction business owners must, therefore, anticipate risk, strike when it is opportune, and effectively manage when there is a threat. This finding is similar to the study by Putniņš and Sauka (2013) who find higher performance as a result of the reward for taking constructive risks. The finding is also in line with Jegede (2018), who states that the lower the risk, the lower the profit. The author adds that a riskless venture hardly possesses any tangible profit and that risk is variability in return.

Entrepreneur's attitude, traits and behaviour are important strategies that enhance entrepreneurial capability and competence for business growth and survival. According to Harvie, Narjoko and Oum (2010), entrepreneurial attitudes are those important characteristics needed by SMEs to upgrade their positions in production networks. This concurs with Markman and Baron (2003) who state that the closer the match between the individual's characteristics and the requirements of being an entrepreneur, the more successful the individual will be. Characteristics of the entrepreneur, which include his socio-demographic characteristics, background characteristics and personality characteristics are necessary for business survival. This finding is also consistent with the previous findings by Gurol and Atsan (2006). An entrepreneurial organization is described as a consciously coordinated social entity, with a relatively identifiable boundary to achieve a common goal or set of goals (Robbins \& Mathew, 2009; Abd-Hamid et al., 
2015). A well-designed organization structure of the construction business, as revealed in this study is an effective strategy fundamental to the survival and success of entrepreneurship. Previous studies also find a strong positive link between organizational structure and entrepreneurship survival of business and construction projects (Shahu, Pandir, \& Ganapathy, 2012).

\subsection{Assessment of the Factors Affecting the Adoption of Survival Strategies for SMCFs}

This section consists of combined data of the perceptions of the respondents on the effect of the 23 factors identified from literature that affect the adoption of survival strategies of entrepreneurship. The combined data were used having ascertained that there is no variation in the perception of the respondents on the effect of factors affecting the adoption of survival strategies for SMCFs in the study area. The result of the analysis, which indicates the MS, SD, rank and remark column indicating the significance of each factor are as presented in Table 7.

Table 7: Factors Affecting the Adoption of Survival Strategies for SMCFs

\begin{tabular}{|c|c|c|c|c|c|}
\hline $\mathbf{S} / \mathbf{n}$. & Factors & Mean score & Std. Deviation & Rank & Remarks \\
\hline 1 & Availability and access to finance & 4.89 & .46 & $1^{\mathrm{st}}$ & VHS \\
\hline 2 & The poor state of the country's infrastructure & 4.81 & .75 & $2^{\text {nd }}$ & VHS \\
\hline 3 & $\begin{array}{l}\text { Poor managerial/executive capacity of the } \\
\text { implementing agencies }\end{array}$ & 4.69 & .85 & $3^{\text {rd }}$ & VHS \\
\hline 4 & Characteristics of entrepreneurs & 4.62 & .94 & $4^{\text {th }}$ & VHS \\
\hline 5 & Failure to adapt to the changing business environment & 4.57 & .87 & $5^{\text {th }}$ & VHS \\
\hline 6 & Low technological capacities & 4.51 & .84 & $6^{\text {th }}$ & VHS \\
\hline 7 & Inadequate business planning & 4.44 & 1.32 & $7^{\text {th }}$ & VHS \\
\hline 8 & Lack of motivation & 4.42 & 1.26 & $8^{\text {th }}$ & VHS \\
\hline 9 & Lack of commitment to solve its problems & 4.41 & 1.14 & $9^{\text {th }}$ & VHS \\
\hline 10 & In-appropriateness of some of the recommendations & 4.37 & 1.24 & $10^{\text {th }}$ & VHS \\
\hline 11 & Corruption & 4.28 & 1.42 & $11^{\text {th }}$ & VHS \\
\hline 12 & Human resources capacities & 3.98 & 1.52 & $12^{\text {th }}$ & HS \\
\hline 13 & Access to information & 3.71 & 1.65 & $13^{\text {th }}$ & HS \\
\hline 14 & Lack of support from expected quarters & 3.63 & 1.67 & $14^{\text {th }}$ & HS \\
\hline 15 & Inconsistent government policies & 3.60 & 1.26 & $15^{\text {th }}$ & HS \\
\hline 16 & Education background & 3.51 & 1.21 & $16^{\text {th }}$ & HS \\
\hline 17 & Networking & 3.45 & 1.18 & $17^{\text {th }}$ & HS \\
\hline 18 & Lack of management skills and training & 3.45 & 1.78 & $18^{\text {th }}$ & HS \\
\hline 19 & Location of the enterprise & 3.22 & 1.68 & $19^{\text {th }}$ & MS \\
\hline 20 & Problems caused by the stakeholders & 3.05 & 1.79 & $20^{\text {th }}$ & MS \\
\hline 21 & Lack of resources for implementation & 2.83 & 1.82 & $21^{\text {st }}$ & MS \\
\hline 22 & Cumbersome legal and regulatory constraints & 2.75 & 1.02 & $22^{\text {nd }}$ & MS \\
\hline 23 & Problems caused by the immediate local community & 2.67 & 1.86 & $23^{\text {rd }}$ & MS \\
\hline
\end{tabular}

The result of Table 7 shows that the rank of the factors range from $2.67 \leq \mathrm{MS} \leq 4.89$, with the most prevalent among the factors being availability and access to finance with $\mathrm{MS}=4.89(\mathrm{SD}=0.46)$; the least ranked factor is problems caused by the immediate local community with MIS = 2.67. Eleven of the factors have very high significance (VHS); five factors have high significance (HS), while the remaining five factors have medium significance (MS). Poor state of the country's infrastructure $(\mathrm{MS}=4.81, \mathrm{SD}=0.75)$ ranks second, followed by poor managerial / executive capacity of the implementing agencies $(\mathrm{MS}=4.69, \mathrm{SD}=0.85)$. Characteristics of entrepreneurs ( $\mathrm{MS}=4.62, \mathrm{SD}=0.94)$ ranks next, while failure to adapt to the changing business environment $(\mathrm{MS}=4.57, \mathrm{SD}=0.87$ ) ranks fifth. Among the least ranks factors are problems caused by the stakeholders ( $\mathrm{MS}=3.05, \mathrm{SD}=1.79)$ and lack of resources for implementation ( $\mathrm{MS}=2.83, \mathrm{SD}=1.82$ ). These also include cumbersome legal and regulatory constraints and problems caused by the immediate local community with
MS $2.75(\mathrm{SD}=1.02)$ and $2.67(\mathrm{SD}=1.86)$ respectively, as shown in Table7.

The findings show that several factors are affecting the adoption of survival strategies for SMCFs which can be categorized into three based on the previous studies, namely: personal characteristics of entrepreneur, internal and external characteristics of an entrepreneurial organization. The prevalent among the factors are further discussed in this section. Availability and access to finance; this factor ranks most by the respondents as affecting the adoption of survival strategies for SMCFs. This factor is a critical issue among construction entrepreneurs in most states of the federation and many developing countries. This result is similar to the finding of a study earlier conducted by Afolabi (2013) who identifies financial constraints explained by high lending rates and high loan requirements as the major cause of the absence of a strong and virile SMEs sub-sector in the Nigerian industrial development process. This was shared by Kim, Knotts and Jones (2008) who argue that limited access to financial resources may restrict more substantial 
investments especially those that require a more extended payback period, creating a growth and development barrier. Findings also show that Chad-Cameroon pipeline project worth US $\$ 4.2$ billion which was one of the most expensive projects funded by the World Bank in Africa at the time failed because World Bank withdrew its financial backing (Fabian \& Amir, 2011). A good entrepreneur as a matter of necessity, should have a sound knowledge of project financing, especially large scale and privately financed projects. A project of this nature is often complex owing to the involvement of several stakeholders, the high costs and risks, and the long duration of project development and the contract duration.

The poor state of the country's infrastructure has been an unresolved problem in the entire nation for several decades. It is not a surprise that this factor is highly ranked in this study. It is a critical issue facing entrepreneurs and concern individuals in the country. The result of the study is in agreement with previous studies by Jegede (2018), the finding reveals associated infrastructural problems such as shortage of water supply, inadequate transport systems, lack of electricity to improper solid waste management as a major factor affecting the survival and growth of SMEs in developing economy. The finding is also consistent with the report of a survey on the competitive performance of 144 economies worldwide conducted by World Economic Forum on Global Competitiveness in 2014 in which Nigeria was ranked low in the quality of its infrastructure (Damoah, 2015). The poor managerial system is a major factor responsible for the failure of implementing the recommended strategy or policy that promotes organizational existence or perhaps using the wrong approach. This is in agreement with Dandira (2011) who notes that even though remarkable progress has been made in the field of strategic management, the problem of strategy implementation failure persists. The problem of the poor managerial system identified in this study is consistent with the findings by Mba and Cletus (2014) who opine that inefficiency in overall business management and poor record-keeping is a major feature of most SMEs. Other challenges include technical problems/competence and lack of essential and required expertise in production, procurement, maintenance, marketing and finances which are also identified as factors that lead to funds misapplication, wrong and costly decision making. The implications are very critical and can eventually lead to the death of the SMCEs.

Findings reveal that the entrepreneur's characteristics are one of the most influential factors that affect business performance and competitiveness in the market (Simpson et al. 2004). These characteristics, among other things, include the age of the entrepreneur, gender, education and family background and previous experience (Guzman \& Santos, 2001; Ucbasaran et al., 2004). These factors can either motivate or demotivate an entrepreneur from being proactive and taking specific actions where necessary. The result of this study is in agreement with the findings by Markman et al. (2007) which relate personal perseverance to a person's capability to persist in the face of difficulties, risks, and failure. The authors maintain that such persons will consistently rise and breakthrough, and as they persevere, they become more skilled and empowered to tackle the next adversity. Inability to manage the ever occurring changes in business environments can as well hinders entrepreneur in achieving success. Changes witnessed in business environments may be from internal or external sources. Internal sources may include changes in project scope, technology, time and cost. External factors, on the other hand, include opportunities, threats, technology, macroenvironmental factors, political climate, and information available in the market which will potentially affect all entrepreneurs, regardless of their background, business sector, or business concept (Dahlqvist, Davidsson \& Wiklund, 2000; Adu \& Ekung, 2019). Findings from previous studies reveal that inability to manage these changes contribute to project failure (Kaliba, Muya \& Mumba, 2009).

\section{Conclusion and Recommendations}

This study investigated survival strategies for SMCFs at infancy stage and factors affecting the adoption of the strategies. Based on the findings above, the study concludes that ensuring the survival of SMCFs at infancy stage depends upon understanding and effective application of specific strategies. The five most dominant among the strategies are: "innovativeness", "required skills", "willingness to take the risk", "entrepreneurial attitudes and behaviours", "entrepreneurial organization structure and strategies", and "financial resource management". Apart from effective management of human and financial resources, entrepreneur competencies and networking in managing entrepreneurial environments are also identified as a panacea for success and survival of SMCFs at the infancy stage. The study also concludes that adoption of the strategies for survival of entrepreneurship is not without challenges which can undermine the effort in achieving the desired goal. Critical among these challenges are: "availability and access to finance", "poor state of the country's infrastructure", "poor managerial/executive capacity of the implementing agencies", "characteristics of entrepreneurs and failure to adapt to the changing business environment". It was further concluded that the respondents had a common view of survival strategies and factors affecting the adoption of these strategies in the study area. Finally, the study concludes that without concerted efforts of government in providing enabling entrepreneurship infrastructure, the gap created in employment generation, national economy and poverty will continue to exist as a result of an increase in the mortality rate of SMCFs at the infancy stage.

This study recommends that to survive in the current dynamic and competitive construction business environment, SMCFs should adopt any or a combination of the strategies highlighted in this study. Owners of SMCFs should also be involved in regular training to acquire the required skills in the management of human and non-human resources. Government through different Support Initiatives and Programmes, should ensure the survival of newly created and registered business firms, especially within the seven years of its existence in the business. There is also a need for a conducive and enabling environment for businesses to thrive through the 
provision of adequate infrastructures. As a way of ensuring the survival of the industry, the government should also set up monitoring and evaluation teams saddled with the responsibility of ensuring steady progress of enterprises and offer advice where necessary. Incentive schemes should be made available for the smooth take-off of newly established SMCFs as well as extending this Initiative to foreign investors. Government policy should help, among other things, to reduce administrative costs and regulatory burden at the same time encouraging SMCFs in accessing loans from commercial banks and lending institutions. A study of this nature should be carried out in other state capitals and

\section{References}

Abd-Hamid, Z, Azizan, N. A., \& Sorooshian, S. (2015). Predictors for the success and survival of entrepreneurs in the construction industry. International Journal of Engineering Business Management, 7(2), 111.

Adcorp (2012). New Business start-ups slump to all time low. [Online] Available: www.adcorp.co.za/NEws/ $\mathrm{P}$ a ge s / N e w busines s s t a r t - u p s s l u m p to a 11 - timelow.aspx> (March 22, 2012).

Adesiyan, B. (2016). Exploring leadership strategies to maximize profitability in the Nigerian housing sector. Doctoral Study Submitted to the Department of Business Administration, Walden University

Adu, E. T., \& Ekung, S. B. (2019). Mitigation measures of price increase of building material

in Uyo metropolis, Nigeria. Ethiopian Journal of Environmental Studies and Management, 12(1), 112 122.

Adu, E. T., \& Oladele, M.A.O. (2018). Challenges and prospects of entrepreneurial development of the masonry block industry in Akwa Ibom State. Conference of the Faculty of Environmental Studies (FESIC), University of Uyo, Uyo, Nigeria, 11th - 14th July, 254266.

Afolabi, M. O. (2013). Growth effect of small and medium enterprises (SMEs) financing in Nigeria. Journal of African Macroeconomic Review, 3(1).

African Economic Outlook (AEO, 2017). Nigeria economic outlook. African development bank group. https://www.afdb.org/en/countries/westafrica/nigeria/nigeria-economic-outlook/

Agwu, M. O., \& Emeti, C. I. (2014). Issues, challenges and prospects of small and medium scale enterprises (SMEs) in Port-Harcourt city, Nigeria. European Journal of Sustainable Development, 3, 1, 101-114 ISSN: 22395938 Doi: 10.14207/ejsd.2014.v3n1p101

Aina, O. C. (2007). The role of SMEs in poverty alleviation in Nigeria [online]. Available at: 238

$<$ http://www.journalanduse.org/Assets/Vol3\%20Pape rs/JOURNAL\%2010.pdf $>$ [Accesse d 13 December, 2009].

Ajayi, Peace, A., \& Mafimidiwo, B. (2012). Construction contractors survival strategies in a depressed economy in Lagos State Nigeria, proceeding of COBRA 2012 held at Las Vegas, Nevada USA on 11-13 September. geo-political zones for comparison and generalization of the findings in Nigeria and developing countries of the world.

\section{Limitations of the study}

The major limitation of the study is the total dependence on the views of the respondents and that the study focused mainly on survival strategies for SMECFs in the construction industry at the infancy stage. The findings might specifically apply only to similar contracting organizations and not the majority of SMCFs.

Ajufo, B. I. (2013). Challenges of youth unemployment in Nigeria. An international multidisciplinary journal, 7(1), 307-321.

Akinsiku, O. E., \& Olubunmi, A. J. (2014). Correlates of clients' payment patterns and construction project performance In Laryea, S. and Ibem, E. (Eds) Proceedings 8th Construction Industry Development Board (cidb) Postgraduate Conference, 10-11 February 2014, University of the Witwatersrand, Johannesburg, South Africa, 223- 232.

Akintoye, A., \& Fitzerald, E. (2002). A survey of current cost estimating practices in the UK. Journal of Construction Management and Economics, 161-172.

Ali, L. K.(2018). An investigation into strategies used by Iraqi SMEs to survive in a hostile environment: the case of Al-Khaleej company. Academy of Entrepreneurship Journal, 24(1), 1-13.

Almus, M. (2002). What characterizes a fast-growing firm? Applied Economics, 34(12), 1497- 1508.

Antoncic, B., \& Hisrich, R.D. (2001). Intrapreneurship: Construct refinement and cross-cultural validation. Journal of Business Venturing. 16(5), 495527.

Arasti, R., Zandi, F., \& Talebi, R. (2012). Exploring the effect of individual factors on business failure in Iranian New established small businesses. International Business Research, 5(4), 2-11. http://dx.doi.org/10.5539/ibr.v5n4p2

Aremu, M. A., \& Adeyemi, S. L. (2011). Small and medium scale enterprises as a survival

strategy for employment generation in Nigeria. Journal of Sustainable Development 4(1),

200-206.

Barbero, J. L. Casillas, J. C., \& Feldman, H.D. (2011). Managerial capabilities and paths to growth as determinants of high-growth small and medium-sized enterprises, International Small Business Journal, 29(6), 671-694.

Baron, R. A., \& Henry, R. A. (2011). Entrepreneurship: The genesis of organisation in Zedeck, S.(Ed.) APA Handbook of Industrial and Organisational Psychology, Washington, DC: American Psychological Association, 1, 241-273.

Bondinuba, F. K. (2012). Exploring the challenges and barriers in accessing financial facilities by small and medium construction firms in Ghana. Civil and Environmental Research, 2(6), 25-35.

Bouazza, A. B., Ardjouman, D., \& Abada, O. (2015). Establishing the factors affecting the growth of small and 
medium-sized enterprises in Algeria. American International Journal of Social Science, 4(2), 101-15.

Chen, S.H., \& Lee, H.T. (2007). Performance evaluation model for project managers using managerial practices. International Journal of Project Management. 25(6), 543-551.

Ciavarella, M., Buchholt, A., Riordan, C., Gatewood, R., \& Stokes, G. (2004). The big five and venture survival: Is there a linkage? Journal of Business Venturing, 19(4), 465- 493.

Collett, N., Pandit, N. R., \& Saarikko, J. (2014). Success and failure in turnaround attempts: an analysis of SMEs within the Finnish restructuring of enterprises act. Entrepreneurship and Regional Development, 26(12), 123-141.

Dahlqvist, J., Davidsson, P., \& Wiklund, J. (2000). Initial conditions as predictors of new venture performance: A replication and extension of the Cooper et al. study. Enterprise and Innovation Management Studies, 1(1), 1-17.

Damoah, I. S. (2015). An investigation into the causes and effects of project failure in government projects in developing countries: Ghana as a case study. A thesis submitted to the requirements of Liverpool John Moores University.

Dana, L. P. (2001). The education and training of entrepreneurship in Asia. Educator + Training,8/9(43), 405-415.

Dandira, M. (2011). Involvement of implementers: Missing element in strategy formulation. Business strategy series, 12(1), 30-34.

Dionco-Adetayo, E. A. (2004). Determinants of small firms' entrepreneurial success in a developing economy. www.sbaer.uca.edu/research accessed 10.11.15.

Diyoke, C.I. (2014). Entrepreneurship development in Nigeria: Issues, problems and prospects.

International Journal of Technical Research and Applications, 10, 19-23.

Drucker, P. F. (1985). Introduction, Innovation and Entrepreneurship, Harper \& Row Publishers, New York, 1-17.

Duell, N. (2011). How to promote self-employment of young people in Europe. Peer review on "Pathways to support young people into self-employment", Analytical Report, Mutual Learning Programme of the European Commission.

Enshassi, A., Al-Hallaq, K., \& Mohamed, S. (2006). Causes of contractor's business failure in developing countries: The Case of Palestine. Journal of Construction in Developing Countries., 11(2), 1-14.

Enshassi, A., Mohammed, S., \& El-Karriri, A. (2010). Factors affecting the bid/no-bid decision in the Palestinian construction industry. Financial and Construction Management Journal, 15(2).

Etim, J. J., Adabu, M. U., \& Ogar, C. A. (2017). Influence of entrepreneurial orientation as a $\sim$ survival strategy for small and medium enterprises: the Nigeria experience. International Journal of Economics, Commerce and Management, 5(8), 502-518.

Etuk, S. E., Offiong, B. O., \& Usip, E.E. (2018). Students` based perceptual evaluation of entrepreneurial studies in Nigeria tertiary institutions. Conference of the Faculty of Environmental Studies (FESIC),
University of Uyo, Uyo, Nigeria, 11th - 14th July, 98104.

Fabian, C., \& Amir, A. (2011). The Chad-Cameroon pipeline project--assessing the World Bank's failed experiment to direct oil revenues towards the poor. The Law and Development Review, 4(1), 32-65.

Fadahunsi, A. (2012). The growth of small business: Towards a research agenda American Journal of Economics and Administration. 4(1), 105-115.

Fatai, A. (2011). Small and medium scale enterprises in Nigeria: The problems and prospects. Available: www.thecje.com/journal/index.php/economicsjournal/art icle/.../8

Gao, Q., \& Banerji, S. (2015). The growth appraisal system for Chinese SMEs. Journal of Chinese

Economic and Business Studies, 13(2), 175-193.

Geroski, P. A., Mata, J., \& Portugal, P. (2010). Founding conditions and the survival of new firms. Strategic Management Journal, 31(5), 510-529.

Gimeno, J., Folta, T. B., Cooper, A. C., \& Woo, C. Y. (1997). Survival of the fittest? Entrepreneurial human capital and the persistence of underperforming firms.

Administrative Quarterly, 42 (4), 750-783.

Gurol, Y., \& Atsan, N. (2006). Entrepreneurial characteristics amongst university students. Education and Training, 48 (1), 25-38.

Gwaya, A. O., Sylvester M. M., \& Walter, O. O. (2014). Development of a Benchmarking Model for Construction Projects in Kenya. International Journal of Soft Computing and Engineering (IJSCE), (4)5. ISSN: 2231-2307.

Hair, J.F.J., Anderson, R.E., Tatham, R.L., \& Black, W.C. (2006), Multivariate Data Analysis, 6th ed., Pearson/Prentice-Hall, Upper Saddle River, NJ.

Hambrick, D., \& Mason, P.A., 1984. Upper echelons: the organization as a reflection of its top managers. Academy of Management Review, 9(2), 193-206.

Harabi, N. (2003). Determinants of firm growth: an empirical analysis from Morocco. MPRA Paper.

Switzerland: University of Applied Science.

Haynes, P. (2003). Differences among entrepreneurs: "Are you experienced?" may be the wrong question.

International Journal of Entrepreneurial Behaviour and Research, 9(3), 111-128.

Hisrich, D. R., Shepherd, A. D., \& Peters, P. M. (2005). Entrepreneurship, 6th Ed: New York, McGrawHill/Irwin.

Hurley, F. R., \& Hult, G. T. (2008). Innovation, market orientation and organizational learning: An integration and empirical examination. Journal of Marketing. 6(2), 42-54.

Ifekwem, N., \& Adedamola, O. (2016). Survival strategies and sustainability of Small and Medium Enterprises in the Oshodi-Isolo local government area of Lagos State. Economics and Business, 4, 103-118. DOI: 10 1515/auseb-2016-0006

Igwe, P. A., Amaugo, A. N., Ogundana, O. M., Egere, O. M., \& Anigbo, J. A. (2018). Factors affecting the investment climate, SMEs productivity and entrepreneurship in Nigeria. European Journal of Sustainable Development, 7(1), 182-200 ISSN: 22395938

Doi: 10.14207/ejsd.2018.v7n1p182 
Igwe, P. A., Newbery, R., White, G. T., \& Nihar, A. (2017). Keeping it in the family: Exploring Entrepreneurial Behaviour in Nigeria. The Institute for Small Business and Entrepreneurship (ISBE) Conference Paper, 8 - 9 November 2017, Belfast, UK.

Jegede, C. A. (2018). Empirical analysis of survival and growth of small and medium scale business in developing economy: The case of Nigeria. Sumerianz Journal of Business Management and Marketing, 1(1), 26-32.

Kaliba, C., Muya, M., \& Mumba, K. (2009). Cost escalation and schedule delays in road construction projects in Zambia. International Journal of Project Management, .27(5), 522-531.

Kazaz, A., Manisali, E., \& Ulubeyli, S. (2008). Effect of basic motivational factors on construction workforce productivity in Turkey. Journal of Civil Engineering and Management, 14(2), 95-106.

Kim, K. S., Knotts, T. L., \& Jones, S. C. (2008). Characterizing viability of small manufacturing enterprises (SME) in the market. Expert Systems with Applications, 34(1), 128-134. https://doi.org/10.1016/j.eswa.2006.08.009

Kothari, C. R. (2004). Research Methodology; Methods and Techniques. New Delhi, India: New Age International Publishers.

Krasniqi, B. A. (2007). Barriers to entrepreneurship and SME growth in transition: The case of Kosova. Journal of Developmental Entrepreneurship, 12(1), 7194.

Kraus, S. (2013). The role of entrepreneurial orientation in service firms: Empirical evidence from Austria. The Service Industries Journal, 33(5), 427-444.

Kumar, R. (2005). Research methodology - A step by step guide for beginners (2nd ed.). Singapore: Pearson Education.

Lee, J. (2001). Education for technology readiness: Prospects for developing countries. Journal of Human Development, 2(1), 115-151.

Lumpkin, G.T., \& Dess G.G. (1996). Clarifying the entrepreneurial orientation construct and linking it to performance. Academy of Management Review. 21(1), 135-172.

Man, T.W.Y, Lau T., \& Chan, K.F. (2002). The competitiveness of small and medium enterprises: A conceptualization with focus on entrepreneurial competencies. Journal of Business Venturing. 17(2), 123-142.

Markman, G., \& Baron, R. (2003). Personentrepreneurship fit: Why some people are more successful as entrepreneurs than others. Human Resource Management Review, 13(2), 281-301.

Martinez, D., Mora, J., \& Villa, L. (2007). Entrepreneurs, the self-employed and employees amongst young European higher education graduates. European Journal of Education, 42(1), 99-117.

Mba, O. A., \& Cletus, I. E. (2014). Issues, challenges and prospects of small and medium scale enterprises (SMEs) in Port-Harcourt city, Nigeria. European Journal of Sustainable Development, 3(1), 101-14.

Mboko, S. \& Smith-Hunter, A. E. (2009). Women entrepreneurs in Zimbabwe: A case study. Journal of Global Business Issues; Spring.
Morse, E.A., Fowler, S.W., \& Lawrence, T.B. (2007). The impact of virtual embeddedness on new venture survival: Overcoming the liabilities of newness. Entrepreneurship Theory \& Practice, 139-159.

Morris, M.H., \& Kuratko, D. E. (2003). Corporate entrepreneurship: The dynamic strategy for 21st Century Organization. Issues in Entrepreneurship: Contracts, Corporate Characteristics and Country Differences, 14, 21-46.

Morris, M.H., \& Sexton, D.L. (1996). The concept of entrepreneurial intensity: Implications for company performance. Journal of Business Research, 36, 5-13.

Naicker, V., \& Saungweme, P. (2009). Strategic alliances governance in Zimbabwe policy and strategy. African Journal of Business Management, 3(8), 325-332.

Ndabeni, L.L. (2008). The contribution of business incubators and technology stations to small enterprise development in South Africa. Development Southern Africa. 25(3), 259-268.

Nwoke, M. D., Adebayo, A. M., \& Olutope, I. V. (2017). Relevance of entrepreneurship education in real estate practice for sustainable entrepreneurship national growth. European journal of educational science, 4(2), 121-135.

Odeyinka, H. A., Kaka, A., \& Mortledge, R. (2013). An evaluation of construction cash flow management approaches in contracting organisation, proceeding of the19th Annual Association of Researchers in Construction Management (ARCOM) Conference held at the University of Brigherence held at the University of Brighton, September 3-5, pp33-41.

Ofori, G. (1994). Practice of construction industry development at crossroads. Habitat International, 18(2), 41-56.

Ogbo, A., \& Agu, A. C. (2012). The role of entrepreneurship in economic development: The

Nigerian perspective. European Journal of Business and Management. 4(8).

Ogunlana, S.O., Promkuntong, K., \& Jearkjirm, V. (1996). Construction delays in a fast-growth economy; comparing Thailand with other economies. International Journal of Project Management, 14(1), 37-45.

Ojo, L. B., Abayomi, A. A., \& Odozi, A.F. (2014). Entrepreneurship education: A viable tool for youth employment in Nigeria. Academic Journal of Interdisciplinary Studies, 3(4).

Okezie, A. I..Alex, O., \& Asoluka, C.N. (2013). Challenges and prospects of entrepreneurship in Nigeria. Academic Journal of Interdisciplinary Studies, 2(5), 2536.

Okpara, J. O. (2009), Entrepreneurial orientation and export performance evidence from an emerging economy. International Business Research Papers, 5(6), $195-211$.

Okpara, O. F. (2007). The value of creativity and innovation in entrepreneurship. Journal of Asia

Entrepreneurship and Sustainability, 3(2), 1-14.

Okumus, F. (2003). A framework to implement strategies in organisations. Management Decision, 41(9), 871-882.

Oladun, M. M. (2012). Entrepreneurial strategies for business success, Lagos, Crystal Publishing House. 
Olagunju, Y. A. (2004). Entrepreneurship and small scale business enterprise development in Nigeria, University Press.

Olawale, F., \& Garwe, D. (2010). Obstacles to the growth of new SMEs in South Africa: A principal component analysis approach. African Journal of Business and Management. 4(5), 729-738.

Olubajo, O. O., \& Kuma, S .S. (2017). Evaluation of factors influencing planning efforts in building projects in Uyo, Nigeria. Journal of Contemporary Research in the Built Environment, 1(2), 95-105.

Olusanya, O. A. (2018). Subcontracting systems and social protection in the informal building construction industry in Lagos, Nigeria. Journal of Construction Business and Management, 2(1). 10-19.

Ongori, H., \& Migiro, S. O. (2010). Information and communication technologies adoption in SMEs literature review. Journal of Chinese Entrepreneurship, 2(1), 93-104.

Onodugo, V., \& Onodugo, C. I. (2015). Impact of socio-cultural factors on entrepreneurial development in Nigeria. African Educational Research Journal Vol. 3(4), 246-254.

Ononogbo, M.C., Joel, A. \& Edeja, S.M.E. (2016). Effect of ethical practices on the corporate image of SMEs in Nigeria: A survey of selected firms in Imo State, International Journal for Research in Business, Management and Accounting 2(8), 35-45.

Osemeke, M. (2012). Entrepreneurial development and interventionist agencies in Nigeria. International Journal of Business and Social Science. 3(8), special edition-April.

Pallant, J. (2007). Survival Manual, A Step by Step Guide for Data Analysis using SPSS for Windows, (3rd ed.). Berkshire, England: McGraw Hill Companies, 368.

Pasanen, M. (2007). SME growth strategies: organic or non-organic?. Journal of Enterprising Culture, 15(317). DOI: 10.1142/S0218495807000174.

Praag, M. C. (2003). Business survival and success of young small business owners. Small Business Economics, 21(1), 1-17.

Putniņš, T. J., \& Sauka, A. (2013). Why Does Entrepreneurial Orientation Affect Company

Performance? Centre of Entrepreneurship, Innovation and Regional Development at Ventspils University College, Discussion Paper 4, 1-36.

Rahman, H., \& Singh H. R. (2014).Entrepreneurial Support and its levels of Success. Global Journal for Research Analysis, 3(11).

Rattanawiboonsom, V., \& Ali, M. M. (2016). Factors affecting entrepreneurial management in Bangladesh: An empirical analysis. Problems and Perspectives in Management, 14(3), 667-690.

Rauch, A, Wiklund J., Lumpkin, G.T., \& Frese, M. (2009). Entrepreneurial orientation and business performance: An assessment of past research and suggestions for the future. Entrepreneurship Theory and Practice. 33, 761-787.

Reijonen, H., \& Komppula, R. (2007). Perception for success and its effect on small firm performance. Journal of Small Business and Enterprise Development, 14(4), 689-701.
Robbins, S. P., \& Mathew, M. (2009). Organization Theory: Structure, Design and Applications. New Delhi: Prentice-Hall.

Ropega, J. (2011). The reasons and symptoms of failure in SMEs. International Advanced Economic Research, 17(4), 476-483. http://dx.doi.org/10.1007/s11294-011-9316-1

Santini, S., Favarin, E. V., Nogueira, M. A., Oliveira, M. L, and Ruppentthal, E. (2015). Factors of mortality in micro and small enterprises: A study in the central region of Rio Grande do Sul. Revista Eletrônica de Estratégia e NegócMveira, ios, 8(1), 145-169.

Scarborough, N.M., Zinmere T.W., \& Wilson, D.I (2008). Effective Small Business Management: An Entrepreneurial Approach, 9th Edition, Prentice-Hall.

Schmalensee, R. (2002). Payment systems and interchange fees. Journal of Industrial Economics. 5(1), 103-122.

Schmidpeter, R., \& Weidinger, C. (2014). Linking business and society: An overview. In $\mathrm{C}$.

Weidinger (Ed.), Business success through sustainability (pp. 287-301). Berlin-

Heidelberg: Springer. https://doi.org/10.1007/978-3642-38753-1_1

Shahu, R., Pandir, A. K., \& Ganapathy, L. (2012). Measuring flexibility degree of building construction projects: A case study. International Journal of Social Science and Interdisciplinary Research, 1(8), 191-197.

Sharma, M. K., \& Bhagwat, R. (2006). Performance measurement in the measurement in the implementation of information systems in small and medium sized enterprises: A framework and empirical analysis. Measuring Business Excellence, 10(4), 8-21.

Sidika, I. (2012). Conceptual framework of factors affecting SME development: Mediating factors on the relationship of entrepreneur traits and SME performance. Proceedings from ICSMED 2012: International Conference on Small and Medium Enterprises Development. Procedia Economics and Finance, 4, $373-383$.

Smith, K. (2018). List of 16 major leading and lagging economic indicators [Blog post]. Retrieved from: http://www.moneycrashers.com/leading-laggingeconomic-indicators/

Sridhar, K., \& Wan, G., 2010. Firm location choice in cities: Evidence from China, India, and Brazil. China Economic Review, 21(1), 113-122.

Taormina, R. J., \& Lao, S. K. M. (2006). Measuring Chinese entrepreneurial motivation - Personality and environmental influences. International Journal of Entrepreneurial Behaviour and Research, 13(4), 200221.

Tarus, D.K. \& Nganga, S.I. (2013). Small and medium size manufacturing enterprises growth and work ethics in Kenya. Developing Country Studies 3(2), 51-59.

Thorpe, E. R., \& Morgan, R. E. (2007). In pursuit of the 'ideal' marketing strategyimplementation. European Journal of Marketing, 41(5/6), 659-677.

Thwala, W. D., \& Phaladi, J. P. (2009). An exploratory study of problems facing small

contractors in the North West province of South Africa. African Journal of Business

Management, 3(10), 533-539. 
Timmons, A. J., \& Spinelli, S. (2004). New venture creation: Entrepreneurship of the 21st century, 4th edition, London: Irwin Press, Burr Ridge.

Turyakira, P. K. (2018). Ethical practices of small and medium-sized enterprises in developing countries: Literature analysis', South African Journal of Economic and Management Sciences 21(1), a1756. https://doi.org/ 10.4102/sajems.v21i1.1756

Ucbasaran, D., Westhead, P., \& Wright, M. (2004). Human capital based determinants of opportunity identification. Retrieved September 24, 2009, from Babson College: http://fusionmx.babson.edu/entrep/fer/BABSON2003 /XVI/XVI-P4/XVI-P4.html

Udofia, E.P. (2011), Applied statistics with multivariate methods. Immaculate Publications Limited, Uyo.

Udoudoh, F. U. (2018). Promoting entrepreneurship and capacity building in real estate development in Nigeria. Conference of the Faculty of Environmental
Studies (FESIC), University of Uyo, Uyo, Nigeria, 11th - 14th July, 105-112.

Undiyaundeye, F., \& Otu, E. A. (2015). Entrepreneurship skills acquisition and the benefits amongst the undergraduate students in Nigeria. European Journal of Social Sciences Education And Research, 5(1), 9-14.

Venkatraman, N. (1989). Strategic orientation of business enterprises: The construct, dimensionality and measurement. Management Science. 35(8), 941-962.

WIEGO (2018). Construction workers publication of women in informal employment: Globalising and Organising. Retrieved from: http://www.wiego.org/informal-economy/occupationalgroup/construction-workers

Wiklund, J., Patzelt, H., \& Shepherd, D. A. (2009). Building an integrative model of small business growth. Small Business Economics, 32 (4), 351-374.

Yusuf, O. T., \& Dansu, S. F. (2013). SMEs, business risks and sustainability in Nigeria.European Journal of Business and Social Sciences, 2(9), 76-94. 